\title{
Rada Federalna i Prezydent Konfederacji Szwajcarskiej. Specyfika i ewolucja rozwiązań kreowania władzy wykonawczej
}

\section{Wprowadzenie}

G łównym aspektem stosunków politycznych jest władza. Problemy takiego zorganizowania i sprawowania władzy w państwie, by działała ona efektywnie, praktycznie od zawsze wzbudzały zainteresowanie prawników, politologów i polityków. Pierwszą koncepcję zorganizowania aparatu państwowego wyrażała zasada jedności (jednolitości) władzy państwowej, zakładająca koncentrację władzy (prawodawczej, wykonawczej, rozstrzygania sporów prawnych) zazwyczaj w rękach jednostki (monarchy), a czasami mniej lub bardziej licznej grupy osób. Istotą przeciwstawnej koncepcji struktury aparatu państwowego - koncepcji władzy podzielonej autorstwa Monteskiusza - jest podział władzy w państwie pomiędzy kilka organów państwowych. Ten francuski myśliciel żyjący w XVIII wieku dążąc do zapewnienia wolności jednostki, wyszedł z założenia, iż władza w państwie winna być podzielona na trzy kategorie: władzę ustawodawczą (legislatywę), wykonawczą (egzekutywę) i sądowniczą (judykatywę). Wedle jego koncepcji istnieje potrzeba takiego zorganizowania i funkcjonowania tych władz, by żadna z nich nie dominowała nad innymi (równowaga i hamowanie władz). Monteskiuszowski trójpodział władzy jest dziś jedną z fundamentalnych zasad, do których odwołują się współczesne demokracje.

Celem rozważań niniejszego tekstu jest analiza specyfiki funkcjonowania instytucji władzy wykonawczej w Konfederacji Szwajcarskiej oraz odpowiedź na pytania o kierunki zmian zachodzących w składzie Rady Federalnej oraz kierunki ewolucji reguł dotyczących wyboru członków szwajcarskiego rządu. Motywacją do podjęcia badań w tym zakresie jest fakt, iż Szwajcaria jest przykładem państwa, gdzie przyjęto specyficzne 
rozwiązania dotyczące wyboru i działania egzekutywy, co wpłynęło na obowiązywanie opinii, że Konfederacja jest jedną z najstabilniejszych demokracji na świecie. Ostatnie lata dowodząjednak, iż praktyka polityczna przekłada się w istotny sposób na ewolucję rozwiązań szwajcarskich, bowiem rozkład sił w parlamencie przyczynił się do odejścia od tzw. magicznej formuły (niem. Zauberformel), która była gwarantem tzw. wielkiej (i jednocześnie stabilnej) koalicji rządowej i do pojawienia się inicjatyw mających na celu zmianę reguł wyboru egzekutywy w tym państwie. Struktura tekstu wspiera się na następujących częściach: po pierwsze, na teoretycznym zarysowaniu modeli funkcjonowania władzy wykonawczej; po drugie, na przedstawieniu płaszczyzny ustrojowej obowiązujących w Szwajcarii rozwiązań; po trzecie, na analizie kierunków ewolucji funkcjonowania szwajcarskiej egzekutywy, ze szczególnym uwzględnieni składu rządu oraz zasad wyboru jego członków. Przedmiot rozważań oraz przyjęta struktura badań wymusiły niejako zastosowanie analizy systemowej oraz analizy instytucjonalno-prawnej jako dwu najistotniejszych (choć nie jedynych) w tym kontekście metod badawczych. Niezwykle pomocne szczególnie przy analizie składu Rady Federalnej w kontekście czynnika płci, okazały się ponadto metody statystyczne i komparatystyczne, pozwalające dostrzec różnice i ich skalę w składzie szwajcarskiego rządu.

\section{Wladza wykonawcza - kontekst teoretyczny}

Mechanizm władzy państwowej w demokracji zakłada wyeliminowanie monokratyzmu, czyli preponderancji jakiegoś jednego ośrodka politycznego. Stąd powszechnie przestrzega się zasady podziału władzy na ustawodawczą, wykonawczą oraz sądowniczą. Współcześnie funkcjonujące systemy rządów oparte na sformułowanej przez Monteskiusza idei podziału władzy są bardzo zróżnicowane. Jak słusznie zauważa A. Gwiżdż, „nie istnieje żaden ściśle wypracowany i szczegółowo zdefiniowany model trójpodziału władzy, który miałby powszechne i pełne poparcie doktryny [...]. W prawie konstytucyjnym różnych krajów systemy ustrojowe oparte na zasadzie trójpodziału występują w różnych wariantach" (Gwiżdż, 1993, s. 13).

Władza wykonawcza - nazywana inaczej egzekutywą - polega na wykonywaniu zadań państwowych mających na celu realizację dobra ogółu społeczeństwa. Do zadań egzekutywy należy bezpośrednie zarządzanie 
sprawami państwa. Władza wykonawcza wprowadza prawa i obowiązki obywateli w życie, jeśli zgodne są one z konstytucją (Patyra, 2010, s. 11). Warto jednocześnie przypomnieć, iż nie może być ona rozumiana wyłącznie jako proste ,wykonywaniem” prawa, czyli stosowanie ustaw i wydawanie aktów prawnych na podstawie upoważnień ustawowych. W praktyce chodzi m.in. o podejmowanie wszelkich działan, których celem jest zapewnienie rozwoju państwa, wzmacnianie autorytetu władzy państwowej, gwarantowanie wolności i praw obywatelskich, sterowanie procesami gospodarczymi, rozwiązywanie problemów społecznych, jak i urzeczywistnianie porządku prawnego. Paweł Sarnecki zauważa, iż funkcja wykonawcza polega m.in. na realizacji: funkcji rządzenia (prowadzenie polityki i kierowania sprawami państwowymi), funkcji zarządzania (ustalanie celów i kierunków realizacji tych ustaw dla podległych organów administracyjnych), funkcji administrowania (sensu stricto - stosowanie ustaw poprzez podejmowanie konkretnych decyzji) (Wojciszko, 2011, s. 48).

W języku potocznym władza wykonawcza kojarzy się jako podrzędna względem tych władz, które odgrywają najważniejszą rolę w procesie stanowienia prawa - czyli władzy ustawodawczej oraz sądowniczej. Tymczasem, jak wskazuje Jean Blondel, władza wykonawcza stanowi główny przedmiot rywalizacji w polityce, a jej struktury tworzą fundament systemu politycznego (Blondel, 2006, s. 246).

W większości państw demokratycznych dla kierowania realizacją podstawowych funkcji państwa w ramach określonych przez ustawy i koordynowania działalności organów wchodzących w skład władzy wykonawczej utworzono specjalny organ, określany zwykle mianem rządu ${ }^{1}$. Jego rola ustrojowa i zadania, a tym samym jego kształt i pozycja osoby stojącej na jego czele, zależą od przyjętej w danym państwie koncepcji władzy wykonawczej. Rola, zadania, a tym samym kształt rządu państwowego oraz pozycja ustrojowa osoby stojącej na jego czele, zależne są od przyjętej w danym kraju koncepcji władzy wykonawczej.

Analiza różnych rozwiązań i cech egzekutywy we współczesnych państwach daje podstawę do dokonania generalizacji i wyodrębnienia kilku modeli władzy wykonawczej. Bogusław Banaszak wskazując, że w państwach demokratycznych przyjęte współcześnie rozwiązania instytucjonalne powtarzają się, wyróżnia następujące modele władzy wykonawczej:

1 Termin „rząd” rozumiany jest tu w jak najszerszym ujęciu. 
1) monokratyczny, 2) dualistyczny, 3) departamentalny oraz 4) dyrektorialny (Banaszak, 2011, s, 134; Banaszak, 2004, s. 537). W modelu monokratycznym $^{2}$ władza wykonawcza skoncentrowana jest zwykle w ręku jednego, jednoosobowego organu - prezydenta, monarchy - w związku z tym w ramach egzekutywy nie występują żadne podziały wewnętrzne. Drugi model zakłada, że władza wykonawcza składa się z dwóch organów: głowy państwa oraz organu kolegialnego - rządu. Oprócz tego, Banaszak wyodrębnia współcześnie występujący trzeci model - departamentalny - charakteryzujący komitetowy system rządów (system rządów zgromadzenia). W czwartym modelu - dyrektorialnym - władza wykonawcza składa się z kadencyjnego kolegialnego dyrektoriatu. Model dyrektorialny współcześnie nie występuje.

Właśnie to trzecie rozwiązanie charakterystyczne jest dla Konfedera-

cji Szwajcarskiej, gdzie przyjęto zasadę, że władza wykonawcza leży w rękach siedmioosobowej Rady Federalnej. W porównaniu z innymi państwami związkowymi w Europie przyjęty przez Szwajcarów model egzekutywy należy do rozwiązań wyjątkowych.

\section{Specyfika rozwiązań szwajcarskich}

Szwajcaria jako państwo federalne charakteryzuje się dość charakterystycznymi rozwiązaniami instytucjonalnymi. Dla pełnego zobrazowania instytucji państwowych niezbędne jest przypomnienie, iż funkcjonują one w specyficznych warunkach geograficznych i politycznych, w obrębie oddziaływania kształtowanej przez stulecia tradycji sprawowania bezpośrednich form władzy. Przez wieki Szwajcaria wypracowała sobie niepowtarzalną i nieistniejącą nigdzie indziej państwowość (Musiał-Karg, 2012, s. 97). Federacja powstawała inaczej niż większość państw w Europie - od dołu do góry. Od samorządnych górskich gmin, poprzez kantony, do związku kantonów, które łącząc się stopniowo ze sobą, utworzyły państwo. Nie bez znaczenia jest fakt, iż Szwajcaria to państwo różnorodne nie tylko pod względem geograficznym, ale i narodowo-społecznym. Po pierwsze, jest państwem składającym się z trzech diametralnie odmiennych regionów geograficznych. Pierwszy z nich to Alpy. Kolejnym jest

2 Występujący w państwach o prezydenckim systemie rządów (USA), w państwach Ameryki Łacińskiej, niektórych krajach należących kiedyś do bloku komunistycznego, a także w niektórych państwach afrykańskich. 
Wyżyna Szwajcarska (Plateau Suisse), na której znajdują się prawie wszystkie (poza Genewą i Bazyleą) największe miasta: Berno, Zurych, Lozanna, Lucerna i Winterthur. Obszar ten jest gęsto zaludniony, a mieszka tam większość ludności Szwajcarii. Ostatnim regionem geograficznym jest pasmo górskie Jury, rozciagające się wzdłuż granicy z Francją, od kantonu o tej samej nazwie na północnym wschodzie po kantony Neuchâtel i Vaud na południowym zachodzie. Po drugie, Szwajcaria podzielona jest na 26 różnych kantonów (w praktyce 23 kantony, z których 3 zostały podzielone na 2 półkantony), które z kolei dzielą się na łącznie 2396 gmin politycznych ${ }^{3}$. Trzecim elementem różnicującym Szwajcarię jest język. W tym państwie mówi się w czterech językach. Około 64\% społeczeństwa posługuje się językiem niemieckim, ponad 20\% włada językiem francuskim, ponad 7\% - włoskim, a niecałe 1\% mówi w języku retoromańskim. Ponadto, różnorodność pod względem religijnym ma także znaczący wpływ na społeczeństwo Szwajcarii. Te wszystkie różnice w dużym stopniu determinują funkcjonowanie demokracji i instytucji państwowych w tym niewielkim państwie federalnym (Musiał-Karg, 2012, s. 97-113).

W Szwajcarii funkcje rządu pełni Rada Federalna. Konstytucja Federalna Konfederacji Szwajcarskiej z dnia 18 kwietnia 1999 r. wskazuje na pozycję ustrojową Rady Federalnej w art. 174, określając ją jako „najwyższą władzę rządzącą i wykonawczą" (Konstytucja Federalna Konfederacji Szwajcarskiej, art. 174). Rada Federalna w swoim orędziu stwierdziła, iż jej pierwszorzędnym zadaniem winno być podejmowanie decyzji wszędzie tam, gdzie wymaga tego sytuacja oraz kreatywne działanie nakierunkowane na przyszłość (Czeszejko-Sochacki, 2000, s. 34). Mimo zasady podziału władzy, szwajcarska konstytucja obfituje w określenia sugerujące na pewnego rodzaju preponderancję parlamentu - Zgromadzenia Federalnego - wobec rządu. Paweł Sarnecki pisze, iż mamy w Szwajcarii do czynienia z podziałem władzy, ale nie jest to równoznaczne $\mathrm{z}$ równowagą tychże władz. Należy zwrócić w tym miejscu uwagę na dwa przepisy ustawy zasadniczej: art. 148 - ,Zgromadzenie Federalne [...] sprawuje

3 W Szwajcarii występuje kilka rodzajów gmin, w tym klasyczne gminy polityczne (ogólne), ale także między innymi gminy kościelne, obywatelskie, szkolne, wyborcze, ubogich; por. R. Schaffhauser, Gmina w Szwajcarii ze szczególnym uwzględnieniem prawa Kantonu St. Gallen, Wrocław-Kolonia 1998; Samorzqd terytorialny $i$ administracja $w$ wybranych krajach. Gmina w państwach Europy Zachodniej, red. J. Jeżewski, Wrocław 1999. 
najwyższą władzę w Federacji” oraz art. 171 umożliwiający parlamentowi zlecanie zadań rządowi. Mimo tego, że rząd może być w pewien sposób kontrolowany czy pobudzany przez parlament, to nie ponosi przed nim odpowiedzialności politycznej sensu stricto.

W skład szwajcarskiej Rady Federalnej wchodzi siedmiu radców federalnych wybieranych przez Zgromadzenie Federalne bezwzględną większością głosów. Wybór Rady Federalnej dokonywany jest na wspólnym posiedzeniu obu izb parlamentu. Wyborów dokonuje się oddzielnie na każde stanowisko rządowe. Zgłaszanie kandydatów polega na wpisaniu nazwiska kandydata na karcie do głosowania. Aby dokonać wyboru potrzebne jest uzyskanie ponad połowy oddanych głosów przez deputowanych (Sarnecki, 2003, s. 259). Jeszcze do niedawna, bo do 2008 r. wybór dokonywany był w oparciu o zasadę tzw. magicznej formuły, określającej reguły reprezentacji partii politycznych, przedstawicieli kantonów oraz wyznań w Radzie Federalnej w Szwajcarii. Formuła nakazywała, by w składzie rządu zawsze były reprezentowane cztery największe partie polityczne, niezależnie od szczegółowych wyników wyborów powszechnych (trzy partie z największym poparciem miały po dwóch przedstawicieli, czwarte pod względem poparcia ugrupowanie - jednego). Stąd w Radzie w latach 1959-2003 zasiadało po dwóch przedstawicieli: Radykalno-Demokratycznej Partii Wolności (FDP), Partii Socjaldemokratycznej Szwajcarii (SPS), Chrześcijańsko-Demokratycznej Partii Ludowej (CVP) i jeden przedstawiciel Szwajcarskiej Partii Ludowej (SVP). W 2003 roku CVP straciła jedno miejsce w rządzie na rzecz SVP. Nadmienić należy, iż przy tworzeniu rządów szwajcarskich trzymano się zasady, by przynajmniej dwóch członków Rady reprezentowało kantony francuskoi włoskojęzyczne. Przez długi okres swych przedstawicieli miały trzy największe kantony: Zurych, Berno i Vaud, zaś żaden kanton nie mógł mieć w Radzie więcej niż jednego przedstawiciela. Oprócz tego, radcy federalni musieli odzwierciedlać odmienność kantonów, języków i religii. Zwracano także uwagę, zwłaszcza po 1971 r., kiedy to kobiety uzyskały prawo wyborcze, na partycypację w rządzie kobiet.

Zasady tworzenia Rady Federalnej sprecyzowane zostały w art. 175 konstytucji i art. 130-134 ustawy federalnej z 13 grudnia 2010 r. o Zgromadzeniu Federalnym (Klöti, Knoepfel, Kriesi, Linder, Papadopoulos, Sciarini, 2006, s. 154 i n.): dokonuje go Zgromadzenie Federalne, tj. 200 członków Rady Narodowej oraz 46 członków Rady Kantonów; nad kandydatami głosuje się indywidualnie, w kolejności od najdłużej sprawującego funkcję członka Rady Federalnej, a głosowanie jest tajne. Zgodnie 
z art. 175 ust. 3 konstytucji, wybranym może zostać każda osoba posiadająca bierne prawo wyborcze do Rady Narodu. W dalszej części artykułu wskazano, by przy wyborze do Rady Federalnej kierować się reprezentacją wszystkich regionów i języków. Zgodnie natomiast z art. 61 ustawy o organizacji rządu i administracji (RVOG) na członka Rady Federalnej nie może zostać wybrana osoba będąca $\mathrm{z}$ inną $\mathrm{w}$ związku małżeńskim, partnerskim lub konkubinacie, krewny w linii prostej lub do czwartego stopnia w linii bocznej. Widoczna zatem jest troska ustawodawcy o to, by radcy byli całkowicie od siebie niezależni.

Obecnie nie stosuje się już przepisu o konieczności wyłaniania radców z różnych kantonów, co przysparzać mogło wielu problemów natury praktycznej. W przypadku Rady Federalnej sprawującej władzę od $2011 \mathrm{r}$. dwie osoby pochodzą z Kantonu Berno. Dodatkowo stosowane są niepisane ograniczenia i zasady, które muszą zostać spełnione przy wyborze członków Rady Federalnej, dzięki czemu instytucja ta staje się jedynym w swoim rodzaju rządem bez opozycji, symbolem ciagłości, stabilizacji i konsensusu.

Przyjęta w Szwajcarii formuła kreowania rządu powodowała, że temu procesowi zwykle nie towarzyszyła taka rywalizacja polityczna, jaką spotyka się w innych państwach demokratycznych. Do 2003 r. nawet kilkuprocentowe zmiany wyników wyborczych czterech partii reprezentowanych w Radzie Federalnej nie skutkowały zmianami w rządzie. Można zatem stwierdzić, że pomimo diametralnych różnic pomiędzy poszczególnymi partiami politycznymi, Szwajcarzy nie żyją w systemie alternatywnych rządów opartych na zasadzie wymienności sterów władzy. System polityczny w tym państwie ukształtował inną metodę - ustanawiając system rządów kolegialnych, którego istotą jest zasada reprezentacji wszystkich sił politycznych na wszystkich szczeblach podziału administracyjnego państwa: na poziomie federalnym, kantonalnym oraz w gminach. W $2007 \mathrm{r}$. w wywiadzie udzielnym tygodnikowi „Polityka” ówczesna prezydent Szwajcarii Micheline Calmy-Rey skonstatowała, że „w systemie alternatywnym przegrani są wykluczeni, nawet odrzuceni do opozycji, również gdy przedstawiają ważną siłę polityczną. U nas [w Szwajcarii - M. M.-K., K.D.] każda ważna siła polityczna po prostu jest w rządzie i musi tam współpracować z innymi. Szukanie dominacji nie służy porozumieniu" (Jak w zegarku, 2007).

Nadmienić warto, iż ponowne wybory dotychczasowych członków rządu przeszły do powszechnej praktyki - jeśli dotychczasowi ministrowie pragną kandydować, zwykle są wybierani po raz kolejny. Dodatkowo, 
w przywoływanej ustawie federalnej o Zgromadzeniu Federalnym znajduje się zapis, że „dotychczasowi członkowie Rady Federalnej podlegają reelekcji w kolejności określonej w oparciu o długość okresu, w którym piastują swoje stanowisko". Możliwość zmiany składu Rady pojawia się w rezultacie rezygnacji radcy federalnego, jego śmierci lub innych przyczyn. Członkowie Rady urzędują średnio około 10 lat, a co istotniejsze - rządu nie można odwołać podczas 4-letniej kadencji. Szwajcaria nie zna instytucji wotum nieufności.

Konstytucja $\mathrm{w}$ art. 177 określa dwie fundamentalne zasady organizacyjne funkcjonowania Rady Federalnej. Pierwszą z nich jest zasada kolegialności, która oznacza, iż każdy akt rządowy musi być przyjęty na wspólnych posiedzeniach radców federalnych, po przegłosowaniu go i po uprzedniej dyskusji. Poprzednia konstytucja mówiła o obowiązkowej dla ważności decyzji Rady obecności 4 z 7 członków rządu. Drugą charakterystyczną zasadą funkcjonowania Rady Federalnej jest zasada departamentalności, konstytuująca utrwalony w systemie szwajcarskim podział prac egzekutywy według określonych departamentów, którymi kierują odpowiedni radcy federalni. Poszczególni radcy występują zatem w dwojakiej roli: po pierwsze, w roli pełnoprawnego członka organu kolegialnego - Rady Federalnej, dysponując przy tym jednakowym wpływem na rozstrzygnięcia i decyzje zapadające w Radzie; po drugie, jako osoby kierujące poszczególnymi działami, dziedzinami administracji federalnej (Krumm, 2013, s. 221). Zgromadzenie Federalne nie przyporządkowuje szefów poszczególnym departamentom - wybiera jedynie członków Rady. Przydział departamentów siedmiu członkom rządu odbywa się in corpore - każdorazowo po wyborach. Wskazany przez kolegium Rady członek rządu obejmuje przydzielony mu departament. Departamenty charakteryzują się dużą autonomią. Obszar ich działania łącznie daje rzeczowy zakres działania Rady Federalnej, który stanowi jednocześnie zakres działalności całej Federacji (Sarnecki, 2003, s. 372).

Jednym z najbardziej charakterystycznych rozwiązań szwajcarskich jest brak wyodrębnionego stanowiska głowy państwa. W przeciwieństwie do innych krajów demokratycznych, gdzie funkcję tę sprawuje prezydent państwa lub monarcha, tytuł Prezydenta Konfederacji Szwajcarskiej nosi przewodniczący Rady Federalnej, czyli szef rządu. Fakt nazywania jego funkcji Prezydentem Federalnym Szwajcarii, nie czyni go jednak głową państwa w takim znaczeniu jak w innych demokracjach. Jest to po prostu członek Rady, którego głównym zadaniem jest przewodniczenie jej obradom (w tym ujęciu możliwe jest porównanie do funkcji premiera). Prezy- 
dent, podobnie jak pozostali członkowie Rady Federalnej, nie ponosi odpowiedzialności politycznej. Nie istnieje również instytucja kontrasygnaty. W Szwajcarii nie obowiązuje także zasada odpowiedzialności prezydenta za delikt konstytucyjny (Grabowska, Grabowski, 2007, s. 269). Ponieważ konstytucja przekazuje wiele typowych dla głowy państwa kompetencji parlamentowi (prawo łaski), rządowi (ratyfikację umów międzynarodowych), przewodniczącym izb parlamentarnych (podpisywanie ustaw), władzom kantonalnym (sprawy dotyczące obywatelstwa), prezydent w Szwajcarii pełni funkcje czysto protokolarne (Sarnecki, 2003, s. 310).

Obok przewodniczenia obradom rządu, podpisywania uchwał Rady i przedstawiania jej oświadczeń w parlamencie, obowiązkiem Prezydenta Federalnego jest pełnienie funkcji głowy państwa. Zgodnie z art. 176 ust. 2 konstytucji, a także art. 134 ustawy federalnej z 13 grudnia 2010 r. o Zgromadzeniu Federalnym, Prezydent wybierany jest z grona Rady przez Zgromadzenie Federalne na okres jednego roku. Na rok wybierany jest również wiceprezydent. Zauważyć należy, że jest to funkcja czysto symboliczna i nie przypisuje się jej istotnego znaczenia. Po roku dochodzi w Radzie Federalnej do rotacji. Zwyczajowo przyjęło się, że wiceprezydent zastępuje prezydenta po upływie jego kadencji. Ustępujący prezydent nie może zostać wskazany na kandydata w kolejnym roku.

Osoba piastująca stanowisko prezydenta nie ma żadnych kompetencji wynikających z posiadanego tytułu. Prezydent jest jedynie uważany za Primus inter pares (Grabowska, Grabowski, 2007, s. 267) i to krótko - przez jeden rok. Jak zaznaczono wcześniej, przewodniczy obradom Rady i sprawuje funkcje reprezentacyjne (np. uczestniczy w ważnych uroczystościach, przyjmuje listy uwierzytelniające od przedstawicieli dyplomatycznych państw obcych). Jako prezydent nie przestaje kierować swoim resortem. Prezydent jednak posiada jedno „mocniejsze” uprawnienie - możliwość wydawania zarządzeń w sprawach pilnych, czyli takich, którymi powinna zająć się Rada, jednak nie można czekać na jej posiedzenie. Takie zarządzenie Prezydenta Rady Federalnej musi zostać zatwierdzone przez Radę na jej najbliższym posiedzeniu. W 2013 r. stanowisko Prezydenta Federalnego pełni Ueli Maurer ze Szwajcarskiej Partii Ludowej. 1 stycznia 2009 r. został wybrany do Rady Federalnej i kieruje departamentem obrony, ochrony cywilnej i sportu. Jego zastępcą jest Didier Burkhalter z Radykalno-Demokratycznej Partii Szwajcarii - jest odpowiedzialny za sprawy zagraniczne. 


\section{Kierunki ewolucji rozwiązań szwajcarskich}

Obecność kobiet w Radzie Federalnej stanowi jeden z pierwszych obszarów ewolucji w kontekście funkcjonowania władzy wykonawczej w Szwajcarii. Mimo iż kobiety w Szwajcarii na szczeblu federalnym uzyskały prawa wyborcze w 1971 r., znamiennym jest fakt, iż do 1984 r. w skład rządu wchodzili wyłącznie mężczyźni. Coraz częściej jednak zwracano uwagę na potrzebę partycypacji pań także i w tym gremium.

Pierwszą kobietą w rządzie była Elisabeth Kopp (FDP), która stanęła na czele departamentu sprawiedliwości i policji. 1 stycznia 1989 r. objęła funkcję wiceprzewodniczącej Rady Związkowej i zgodnie z tradycją polityczną Szwajcarii miała szanse zostać pierwszą kobietą-prezydentem w kolejnym roku. W związku z (jak się okazało bezpodstawnymi) zarzutami o łamanie tajemnicy państwowej, Kopp 12 stycznia 1989 r. podała się do dymisji (Elisabeth Kopp...).

Cztery lata później, 10 marca 1993 r. do Rady Federalnej wybrana została socjaldemokratka - Ruth Dreifuss, która w latach 1994-2002 kierowała sprawami wewnętrzni, w 1998 r. pełniła funkcje wiceprezydenta Rady, a w 1999 r. została pierwszą kobietą prezydentem.

Niewątpliwie, znamiennym okazał się rok 2010, w którym po wyborze Simonetty Sommaruga, po raz pierwszy w siedmioosobowej Radzie Federalnej kobiety stanowiły większość (prócz wspomnianej S. Sommaruga, w składzie rady były również Micheline Calmy-Rey, Doris Leuthard oraz Eveline Widmer-Schlumpf). Szczegółowe dane dotyczące składu Rady Związkowej poszczególnych kadencji zawarto w tabeli 1.

Tabela 1

Kobiety w Radzie Federalnej (1984-2013)

\begin{tabular}{|c|c|c|c|c||}
\hline & $\begin{array}{c}\text { Liczba } \\
\text { kobiet }\end{array}$ & $\begin{array}{c}\text { Liczba } \\
\text { mężczyzn }\end{array}$ & $\begin{array}{c}\text { Udzial kobiet } \\
\mathbf{( \% )}\end{array}$ & $\begin{array}{c}\text { Przynależność } \\
\text { partyjna kobiet }\end{array}$ \\
\hline 1 & 2 & 3 & 4 & 5 \\
\hline do 1984 & 0 & 7 & 0,0 & - \\
\hline $1984-1989$ & 1 & 7 & 14,3 & FDP \\
\hline $1989-1993$ & 0 & 7 & 0,0 & - \\
\hline $1993-1999$ & 1 & 6 & 14,3 & SPS \\
\hline $1999-2003$ & 2 & 5 & 28,6 & CVP, SPS \\
\hline $2004-2006$ & 1 & 6 & 14,3 & SPS \\
\hline $2006-2007$ & 2 & 5 & 28,6 & CVP, SPS \\
\hline $2008-2010$ & 3 & 4 & 42,9 & CVP, SPS, BDP \\
\hline
\end{tabular}




\begin{tabular}{||c|c|c|c|c||}
\hline 1 & 2 & 3 & 4 & 5 \\
\hline $2010-2011$ & 4 & 3 & 57,1 & CVP, SPS (2), BDP \\
\hline $2012-2013$ & 3 & 4 & 42,9 & CVP, SPS, BDP \\
\hline
\end{tabular}

Źródło: Bundesamt für Statistik, opracowanie własne.

W latach 1999-2003 do Rady Federalnej dołączyła Ruth Metzler-Arnold (CVP), która stała na czele Federalnego Departamentu Sprawiedliwości i Policji. Po ustąpieniu R. Dreiffus do rządu wybrano Micheline Calmy-Rey (SPS), która do końca roku 2011 była odpowiedzialna za sprawy zagraniczne Szwajcarii. Calmy-Rey dwukrotnie pełniła urząd prezydenta - w roku 2007 i 2011. Kolejna kobieta - Doris Leuthard (CVP) została wybrana w roku 2006: kierowała departamentem spraw ekonomicznych (2006-2010), a od 2010 r. jest odpowiedzialna za transport, łączność i energetykę. W roku 2008 do Rady Związkowej dołączyła Eveline Widmer-Schlumpf (wcześniej SVP, obecnie BDP), która w latach 2008-2010 zajmowała się kwestiami sprawiedliwości i policji, a następnie objęła funkcje radcy federalnego odpowiedzialnego za finanse państwa. E. Widmer-Schlumpf w roku 2012 była prezydentem Konfederacji Szwajcarskiej. Ostatnią kobietą, która została wybrana do rządu jest Simonetta Sommaruga (SPS), kierująca od 2010 r. departamentem sprawiedliwości i policji.

W całej historii Rady Federalnej na 115 rad federalnych w jej składzie zasiadało tylko 7 kobiet. Po tym jak Szwajcaria przyznała kobietom prawa wyborcze dopiero w 1971 r., a niektóre kantony (np. oba Appenzell) zwlekały z podjęciem podobnej decyzji na szczeblu kantonalnym, przewaga pań w rządzie federalnym w 2010 r. miała niewątpliwie charakter symboliczny.

Drugi wymiar zmian związanych ze szwajcarską egzekutywą dotyczy zmiany składu partyjnego ,ustanowionego" za pomocą magicznej formuły. Struktura partyjna Rady Federalnej nie uległa zmianie przez 44 lata: od 1959 r. aż do roku 2003. W 2003 w wyniku zwycięstwa wyborczego najmniejszej do tego czasu partii - SVP doszło do modyfikacji formuły magicznej. Odtąd SVP miała swoich dwóch przedstawicieli w Radzie (zamiast jednego), a partia chadecka (CVP) straciła jedno miejsce, pozostając z jednym swoim reprezentantem w rządzie. To długie trwanie helweckiej koalicji rządowej przyczyniło się do opinii, że szwajcarska Rada Federalna jest jednym z najstabilniejszych rządów świata (Bankowicz, 2006, s. 101).

Przez długi okres (1959-2003) magiczna formuła funkcjonowała bez zarzutu i była niezmienna (Linder, 2005, s. 227). W 2003 r. po dwukrot- 
nym wygraniu wyborów przez SVP (w 1999 roku i w 2003 roku) partia ta urosła do największej siły w Radzie Narodowej. Jednocześnie CVP uzyskała najsłabszy wynik (14,4\%) (Linder, 2009, s. 571). Wygrana SVP i uzyskanie przez nią wyniku $27 \%$ spowodowało, że w trakcie wspólnego posiedzenia obu izb parlamentu, które obyło się 10 grudnia 2003 r., partia zażądała miejsca w rządzie dla swojego lidera, Christopha Blochera, grożąc przy tym, że w przeciwnym razie przejdzie do opozycji. Argumentowano, że partia ma prawo do posiadania drugiego członka w rządzie. Lider partii kandydował wówczas na miejsce Ruth Metzler-Arnold w Departamencie Sprawiedliwości i Policji, z którą wygrał w III turze głosowań. Wydarzenie to było znamienne przede wszystkim z powodu złamania dotychczasowej tradycji wyboru urzędującego radcy, o ile ten wyraża taką chęć. Od tego czasu podział miejsc w rządzie wyglądał następująco: SVP - 2, SPS - 2, FDP - 2, CVP - 1. Liczba partii wchodzących w skład rządu jednak się nie zmieniła. Przywołany podział przetrwał jednak jedynie cztery lata.

12 grudnia 2007 r. magiczna formuła zmieniona została w sposób bardziej radykalny. W wyniku kolejnych wyborów parlamentarnych zwycięstwo odniosła Szwajcarska Partia Ludowa. Zyskały jednocześnie Partia Socjaldemokratyczna i Zieloni. Problemem okazała się tym razem pozycja Ch. Blochera, który od czterech lat był członkiem rządu. Uformowała się wówczas koalicja parlamentarna, która optowała za wybraniem na jego miejsce mniej kontrowersyjnego polityka. W wyborach do Rady Federalnej nie przedłużono kadencji Blochera, wybierając w drugim głosowaniu na jego miejsce E. Widmer-Schlumpf. Ogłoszono wówczas, że od 1 stycznia 2008 r. SVP przechodzi do opozycji. Przed Blocherem nieprzedłużenie posady ministra zdarzyło się tylko trzy razy, z czego dwukrotnie w XIX wieku, a następnie w 2003 r. (Surdel, 2007). Widmer-Schlumpf mimo braku poparcia ze strony SVP, zaakceptowała wybór, podobnie zresztą jak reelektowany Samuel Schmid (również z SVP). Zdecydowano zatem o ich wykluczeniu z frakcji. Po raz kolejny zatem złamano przyjęte założenia konkordancji, mówiące między innymi o przedłużaniu mandatu członka rządu, jeśli ten ubiega się o to. Sytuacja jeszcze bardziej skomplikowała się w kwietniu 2008 r., kiedy SVP zażądała od E. Widmer-Schlumpf rezygnacji z funkcji radcy oraz zrzeczenia się przez nią mandatu członka partii. Zagrożono, że w innym przypadku konieczne będzie jej wykluczenie ze struktur kantonalnych, a jeśli tak się nie stanie, to sama struktura poniesie konsekwencję niepodjęcia decyzji w sprawie Widmem-Schlumpf. W związku z brakiem stosownej decyzji, usunięto 
z SVP całąjej gryzońską część, z której utworzono najpierw Szwajcarską Partię Obywatelską, a po połączeniu z sekcją z Berna (gdzie miała miejsce podoba sytuacja z S. Schmidtem), Demokratyczną Partię Obywatelską (BDP). W związku z powyższym przez krótki okres BDP posiadała 2 członków w Radzie, SPS i FDP również po dwóch, a CVP - jednego. Samuel Schmid zrezygnował z funkcji członka rządu wraz z końcem 2008 roku. 10 grudnia 2008 r. większością zaledwie jednego głosu, stosunkiem 122 do 121 głosów, nowym członkiem Szwajcarskiej Rady Związkowej oraz ministrem obrony wybrany został Ueli Maurer z SVP, który wystawiony został jako kandydat tej partii wraz z Ch. Blocherem (Swiss People's Party...). Od 2009 r. podział miejsc w Radzie federalnej jest następujący: SVP - 1, SPS - 2, FDP - 2, CVP - 1, BDP - 1 .

W 2010 r. w związku z rezygnacją dwóch członków Rady - Moritz Leuenbergera (SPS) i Hansa-Rudolfa Merza (FDP) - na miejsce tego pierwszego wybrana została Simonetta Sommaruga (również z SPS), zaś w ramach przedstawicielstwa FDP - Johann Schneidera-Ammanna.

Wybory do parlamentu z $2011 \mathrm{r}$. nie przyniosły radykalnych zmian w podziale partyjnym rządu. Niepewna była obecność BDP, która pozyskała część wyborców SVP. Mimo straty części głosów (na rzecz BDP) partia ludowa pozostała najsilniejszym ugrupowaniem. BDP uzyskało jedynie 5,4\% głosów, co umożliwiło uzyskanie dziewięciu mandatów w parlamencie. Mimo chęci przywrócenia przez SVP kształtu magicznej formuły sprzed dziesięciu lat i wystawienia przeciw E. Widmer-Schlumpf dwóch kontrkandydatów (Jean-François Rime i Bruno Zuppiger), to właśnie ją wybrano ponownie, co było symbolicznym powrotem do złamanej dwukrotnie w ostatnim okresie $(2003,2007)$ zasady przedłużania wyboru dotychczasowych radców. W związku z przejściem Micheline Calmy-Rey (SPS) na emeryturę, w wyniku wyboru uzupełniającego z ramienia socjaldemokratów wybrany został Alain Berset ${ }^{4}$.

\section{Proponowane sposoby wyboru Rady Federalnej}

Zasada wyboru egzekutywy oparta na magicznej formule gwarantuje dążenie do osiaggania kompromisowych rozwiązań w szwajcarskiej polity-

4 W 2013 r. w skład Rady Federalnej wchodzili: Johann Schneider-Ammann (FDP), Didier Burkhalter (FDP), Simonetta Sommaruga (SPS), Alain Berset (SPS), Eveline Widmer-Schlumpf (BDP), Ueli Maurer (SVP), Doris Leuthard (CVP). 
ce. Konsensus ten jest bowiem istotnym elementem politycznego krajobrazu państwa określanego jako swoista mozaika języków, tradycji, kultur i wspólnot lokalnych. Jak zauważa Wolf Linder, w tak zróżnicowanym kraju każdy odmienny sposób powoływania rządu mógłby zawodzić. Należy jednak pamiętać, iż podział miejsc w ramach magicznej formuły jest nieformalny i może zostać w każdej chwili całkowicie zastąpiony przez klasyczny system wyłaniania rządów. Pełni jednak ważną rolę do dziś i mimo swej zmiany w 2003 roku nadal jest w stanie spełniać swoje zadanie (Linder, 2009, s. 573).

Odnotować należy, iż pierwsza inicjatywa w zakresie zmian sposobu wyboru członków Rady Federalnej pochodzi z 1899 r., kiedy to środowiska związane z Partią Socjaldemokratyczną i Partią Katolicko-Konserwatywną, a także związki zawodowe wyszły z inicjatywą bezpośredniego wyboru Rady i zwiększenia jej liczby do 9 . W wyniku referendum z 4 listopada 1900 r. inicjatywa została odrzucona przez 65\% głosujących przy frekwencji na poziomie 58,8\%. Za przyjęciem zagłosowało wówczas $72 / 2$ kantonu. Zgodnie $\mathrm{z}$ obowiązującą wówczas konstytucją, do przyjęcia zmian potrzebne było uzyskanie tzw. podwójnej większości: większości głosujących oraz większości głosów „kantonalnych”.

Tabela 2

Wyniki referendów w zakresie bezpośrednich i powszechnych wyborów Rady Federalnej

\begin{tabular}{|l|c|c|c||}
\hline & $\mathbf{4 . 1 1 . 1 9 0 0}$ & $\mathbf{2 5 . 0 1 . 1 9 4 2}$ & $\mathbf{9 . 0 6 . 2 0 1 3}$ r. \\
\hline Za & $35,0 \%$ & $32,4 \%$ & $23,7 \%$ \\
\hline Przeciw & $65,0 \%$ & $67,6 \%$ & $76,3 \%$ \\
\hline Frekwencja & $58,81 \%$ & $61,97 \%$ & $39,52 \%$ \\
\hline Kantony „za” & $7 \% / 2$ & 0 & 0 \\
\hline Kantony „przeciw” & $12 \% / 2$ & $19 \% / 2$ & $20 \% / 2$ \\
\hline
\end{tabular}

Źródło: Bundesamt für Statistik, opracowanie własne.

W 1939 r. ponownie pojawił się pomysł powszechnych wyborów Rady. W kolejnej inicjatywie proponowano rozszerzenie Rady Federalnej z siedmiu do dziewięciu członków. Inicjatywa została odrzucona większością 67,6\% głosujących.

We wrześniu 2008 r. socjaldemokratyczna członkini Rady Federalnej Micheline Calmy-Rey poruszała kwestię wyboru Rady w wyborach powszechnych. Ideę poparł członek Rady Narodu - Josef Zisyadis z Partii Pracy, który proponował wprowadzenie zmian do konstytucji z inicjatywy 
parlamentu. Proponowano by, wybory do Rady Federalnej odbywały się w sposób proporcjonalny. Wniosek Zisyadisa został odrzucony przez Komisję Polityki Państwowej Rady Narodu.

W 2010 r. Szwajcarska Partia Ludowa rozpoczęła akcję zbierania podpisów pod inicjatywą ludową „Wybory powszechne Rady Federalnej”. W jej wyniku odbyło się referendum, w którym po raz trzeci społeczeństwo odrzuciło pomysł powszechnych wyborów członków szwajcarskiego rządu.

W kontekście debaty nad pomysłem bezpośredniego wyboru Rady Federalnej wylicza się szereg zalet, jak i wad płynących z proponowanych zmian. Zwraca się uwagę przede wszystkim na kwestię zwiększenia praw obywateli, co jest zgodne $\mathrm{z}$ tendencją przekazywania licznych kompetencji społeczeństwu poprzez demokrację bezpośrednią. Wymienia się także fakt, iż dzięki bezpośredniej demokracji obywatele mają wpływ na bardzo wiele spraw związanych z funkcjonowaniem państwa i jego kantonów, czy gmin (w tym na poziomie federacji za pomocą narzędzi inicjatywy ludowej i referendum, a na poziomie kantonalnym i gminnym dodatkowo jeszcze za pomocą instytucji Landsgemeinde), nie mają natomiast możliwości bezpośredniego wyboru organu federalnej władzy wykonawczej. Kolejną z wymienianych zalet jest możliwość silniejszej legitymizacji egzekutywy, która dzięki wyborom powszechnym byłaby odpowiedzialna bezpośrednio przed społeczeństwem. Wskazuje się także, że w wyniku powszechnych wyborów działalność w Radzie byłaby bardziej przejrzysta. Nie byłyby zatem możliwe „gry taktyczne" parlamentu.

Na niektóre $\mathrm{z}$ wad tego rozwiązania zwróciła uwagę sama Rada Federalna, w której materiałach zaakcentowano, że w konsekwencji wyborów powszechnych członków egzekutywy Rada Federalna nie stałaby ,ponad" polityką, a jej członkowie byliby związani nie tylko instrukcjami partyjnymi, ale także odpowiedzialnością przed wyborcami ${ }^{5}$. Wpływałoby to w znaczący sposób na poziom obiektywizmu w kontekście podejmowanych przez rząd rozwiązań. Sami członkowie Rady musieliby niejako bardziej skoncentrować się nie na wypracowywaniu kompromisów w działalności politycznej, ale byliby bardziej skłonni do budowania swojego wizerunku przed wyborcami, do prowadzenia kampanii wyborczej, czy na obecności w mediach. Problematyczne byłoby wówczas także zastosowanie dotychczas obowiązującej zasady kolegialności. Jedną

5 Broszura Botschaft zur Volksinitiative „Volkswahl des Bundesrates”. 
z konsekwencji powszechnych wyborów Rady byłoby zapewne osłabienie roli Zgromadzenia Federalnego. Należy ponadto zwrócić uwagę, że już teraz istnieje problem $z$ reprezentowaniem obszarów słabiej zaludnionych i małych kantonów, w związku z czym odpowiednia reprezentacja w Radzie powyższych regionów mogłaby zostać zagrożona zbyt dużą reprezentacją przedstawicieli dużych miast i aglomeracji. Jednym z problemów może być również mniejsze zaangażowanie radców w prace rządu w czasie trwania kampanii wyborczej. Ostatnim z problemów może być kwestia zapewnienia w Radzie Federalnej obecności co najmniej dwóch osób pochodzących z łacińskiego obszaru językowego Szwajcarii. W praktyce pomija to osoby posługujące się językiem retoromańskim, a także przeciwstawia się wówczas sobie w postaci konkurencji Romandię z kantonem Tessin, który także straciłby z powodu małej liczby mieszkańców.

W kontekście ewoluowania szwajcarskich rozwiązań ustrojowych, zwraca się także uwagę na możliwość powstania w Szwajcarii systemu opartego o model konkurencyjny oparty na tworzeniu mniejszych koalicji (Krumm, 2013, s. 3). Spowodowałoby to jednak prawdopodobnie odejście od demokracji konsocjonalnej funkcjonującej w federacji. Nowe możliwości koalicyjne zyskałyby w tym przypadku przede wszystkim średnie i mniejsze partie, które zwykle ze względu na dużą zdolność koalicyjną są języczkiem u wagi szczególnie po wyborach (w tym przede wszystkim Partia Zielonych i Liberalna Partia Zielonych, niereprezentowane dotąd w koalicji). Również Linder wskazuje, że jednym z możliwych scenariuszy jest powstanie polaryzującego się systemu konkurencyjnego (Linder, 2005, s. 328). Wskazuje, że konieczna była wówczas przebudowa szwajcarskiego systemu politycznego, włączając $\mathrm{w}$ to stworzenie możliwości organizowania powszechnych wyborów Rady. Inną możliwością jest reforma powstawania koalicji poprzez stworzenie systemu konkurencyjnego jedynie na czas konstruowania rządu. Umożliwiłoby to tworzenie zarówno wielkich koalicji, jak wcześniej, ale też innych - centrolewicowych i centroprawicowych (Linder, 2005, s. 330).

\section{Wnioski}

Niniejsze rozważania skłaniają do sformułowania kilku - wydaje się - istotnych wniosków związanych z odpowiedziami na postawione wcześniej pytania badawcze. 
1. Funkcjonowanie szwajcarskiej Rady Federalnej podlega ewolucji, która obserwowalna jest $\mathrm{w}$ trzech wymiarach: pojawieniu się kobiet w helweckim rządzie, zmian w strukturze i układzie sił politycznych w egzekutywie oraz w dążeniach do zmiany sposobu wyboru radców federalnych.

2. O ile ten pierwszy - nazwijmy to umownie kontekstem ptci-nie ma większego znaczenia, to już dwa pozostałe zdają się mieć charakter kluczowy - wiążą się bowiem z modyfikacją lub odejściem od magicznej formuły, która jest jednym z najbardziej charakterystycznych elementów porządku ustrojowego Konfederacji Szwajcarskiej.

3. Zwiększenie liczby partii posiadających w rządzie swoich przedstawicieli, może przełożyć się na dwa scenariusze: po pierwsze, co mało prawdopodobne, na odejście od formuły tzw. wielkiej rządowej koalicji i przyjęcie rozwiązań charakterystycznych dla innych państw demokratycznych; po drugie - na skłonienie niejako partii rządowych do jeszcze większego wysiłku na rzecz osiagania politycznych kompromisów i zapewnienia stabilności szwajcarskiej egzekutywy.

4. W wyniku zmian liczby partii w szwajcarskim rządzie magiczna formuła wydaje się nie tyle „upaść”, co raczej zostać „zmodyfikowana”. Warto zauważyć, iż istnieje szansa na powrót do pierwotnej konstrukcji formuły po zmianie układu sił politycznych w parlamencie. Wymagałoby to jednak ukształtowania się takiej sytuacji politycznej, gdzie trzy największe partie w parlamencie uzyskałyby w wyborach takie poparcie, które „zdystansowałoby” czwartą w kolejności partię. Jednym z rozwiązań „modyfikujących” magiczna formułę mogłoby być takie, którego istotą byłoby dzielenie miejsc $\mathrm{w}$ rządzie proporcjonalnie do uzyskanego w wyborach poparcia. W tym jednak przypadku formuła $2+2+2+1$ mogłaby być trudna do osiagnięcia - szczególnie w sytuacji rozdrobnienia na szwajcarskiej scenie politycznej. W skrajnych przypadkach - uzyskania podobnego poparcia przez siedem partii lub bezdyskusyjnego zwycięstwa dwóch lub trzech partii - do rządu mogliby wejść przedstawiciele odpowiednio siedmiu lub trzech ugrupowań. W tych zaś sytuacjach kompromis lub interes wszystkich grup językowych, religijnych itd. byłby zapewne trudniej osiagalny.

5. Inicjatywy zmiany sposobu wyboru członków Rady Federalnej wydają się nie padać na podatny grunt, czego dowodem są przegrane głosowania powszechne w tej sprawie - szczególnie to z czerwca $2013 \mathrm{r}$.

Reasumując, zauważyć należy, iż w Szwajcarii stworzony został specyficzny, niespotykany w innych państwach, system polityczny. Konstytu- 
cja i normy zwyczajowe umożliwiają każdej grupie społecznej posiadanie swego przedstawicielstwa na każdym szczeblu władzy. Reelekcja sprzyja ciągłości i przewidywalności działań egzekutywy, zaś kooperacja między partiami pozwala uniknąć częstych zatargów i przetasowań na scenie politycznej. Oczywistym jest fakt, iż im większa liczba koalicjantów w rządzie, tym kompromis polityczny może być trudniejszy do osiagnięcia. Jednak osiagnnięcie porozumienia zwiększają instytucje demokracji bezpośredniej, dzięki którym społeczeństwo bierze aktywny udział w prowadzonej przez państwo polityce.

W związku z powracającą dyskusją na temat konstruowania szwajcarskiej Rady Federalnej, pojawiają się opinie o konieczności przyjęcia do konstytucji zapisów prawnych, które regulowałyby skład rządu. Mimo zgłaszanych petycji, komisja Rady Narodowej uznała, że nadanie ustawowego charakteru magicznej formuły byłoby niezgodne $\mathrm{z}$ art. 175 ust. 3 konstytucji, dotyczącego wyboru członków rządu spośród wszystkich obywateli mających bierne prawo wyborcze do Rady Narodu (Kosowska-Gąstoł, 2012, s. 94).

Warto w tym miejscu ponownie przywołać słowa Micheline Calmy-Rey wskazujące, że szwajcarski system, szwajcarskie instytucje polityczne, „oferują ludziom różnych kultur i poglądów pokojową koegzystencję, możliwość życia razem [...] To - w połączeniu z demokracją bezpośrednią - sprawia, że rząd musi nie tylko unikać skrajności, ale więcej: żeby rządzić, musi stale dążyć do porozumienia ze wszystkimi, stale brać pod uwagę różne wrażliwości” (Jak w zegarku, 2007).

\section{Bibliografia}

Banaszak B. (2004), Porównawcze prawo konstytucyjne wspótczesnych państw demokratycznych, Zakamycze.

Banaszak B. (2011), Szef rządu we wspótczesnych systemach ustrojowych, „Przegląd Prawa Konstytucyjnego", $\mathrm{nr} 2$.

Bankowicz M. (2006), Demokracja. Zasady, procedury, instytucje, Kraków.

Blondel J. (1995), Comparative Government. An Introduction, London 1995.

Broszura Botschaft zur Volksinitiative „Volkswahl des Bundesrates”.

Czeszejko-Sochacki Z. (2000), Wstęp, w: Konstytucja Federalna Konfederacji Szwajcarskiej z dnia 18 kwietnia 1999 r., Wstęp: Z. Czeszejko-Sochacki, Warszawa. 
Elisabeth Kopp, Federal Councillors Since 1984, The Swiss Federal Council, http:/www.admin.ch/br/dokumentation/mitglieder/details/index.html?lang= en\&id=98, 15.07.2012.

Grabowska S., Grabowski R. (2007), Prawo wyborcze na urzad prezydenta w państwach europejskich, Warszawa.

Gwiżdż A. (1993), Ustawodawstwo i kompetencje prawotwórcze rzqdu (w świetle ustawy konstytucyjnej z 17 X 1992 roku), w: ,Mała konstytucja” w procesie przemian ustrojowych $w$ Polsce, red. M. Kruk, Warszawa.

Jak w zegarku, rozmowa M. Ostrowskiego z prezydent Szwajcarii Micheline Calmy-Rey, „Polityka” 2007, nr 20.

Jeżewski J. (red.), Samorzad terytorialny i administracja w wybranych krajach. Gmina w państwach Europy Zachodniej, Wrocław 1999.

Klöti U., Knoepfel P., Kriesi H., Linder W., Papadopoulos Y., Sciarini P. (2006), Handbuch der Schweizer Politik. Manuel de la politique suisse, Zurich.

Konstytucja Federalna Konfederacji Szwajcarskiej z dnia 18 kwietnia 1999 r., art. 174, w: Konstytucja Federalna Konfederacji Szwajcarskiej z dnia 18 kwietnia 1999 r., Wstęp: Z. Czeszejko-Sochacki, Warszawa 2000.

Kosowska-Gąstoł B. (2012), Zmiany zasad tworzenia rzadu w Konfederacji Szwajcarskiej, „Państwo i Prawo”, nr 12.

Krumm T. (2013), Das politische System der Schweiz. Ein international Vergleich, O1denbourg, München.

Linder W. (2005), Schweizerische Demokratie. Institutionen - Prozesse - Perspektiven, Bern-Stuttgart-Wien.

Linder W. (2009), Das politische System der Schweiz, w: Die politischen Systeme Westeuropas, red. W. Ismayr, Wiesbaden.

Musiał-Karg M. (2012), Elektroniczne referendum $w$ Szwajcarii. Wybrane kierunki zmian helweckiej demokracji bezpośredniej, Poznań.

Patyra S. (2010), Prawnopolityczne instrumenty oddziaływania rzqdu na proces ustawodawczy w systemie rzqdów parlamentarnych na przykładzie Wielkiej Brytanii i Francji, „Przegląd Prawa Konstytucyjnego” nr 2-3.

Sarnecki P. (2003), Ustroje konstytucyjne państw współczesnych, Zakamycze.

Surdel T., Rewolucja w Szwajcarii, „Gazeta Wyborcza”, 18.12.2007 r.

Swiss People's Party rejoins coalition government, „The New York Times”, http://www.nytimes.com/2008/12/10/world/europe/10iht-swiss.4.18567360.html?_r=1, 23.03.2010 r.

Wojciszko M. (2011), Prawnoustrojowa pozycja wybranych organów państwa (ze szczególnym uwzględnieniem naczelnych organów), $w$ realizacji zadań $w o b-$ szarze bezpieczeństwa i obronności, „Wojskowy Przegląd Prawniczy”, z. 4.

Schaffhausen R. (1998), Gmina w Szwajcarii ze szczególnym uwzględnieniem prawa Kantonu St. Gallen, Wrocław-Kolonia. 
The Federal Council and the President of the Swiss Confederation. The specific nature and evolution of solutions creating executive power

\begin{abstract}
Summary
Switzerland is an example of a state that has adopted specific solutions as regards the election and execution of executive power, which has generated the common conviction that the Swiss Confederation is among the most solid democracies in the world. Recent years have shown, however, that political practice has brought about a significant evolution of Swiss solutions as the distribution of power in the parliament has resulted in the abolition of the 'magical formula' that guaranteed the great (and stable) government coalition, and the emergence of initiatives aiming at changing the principles along which executive power is elected in Switzerland. The purpose of considerations presented in this paper is to analyze the specific character of how the executive institutions function in the Swiss Confederation, answer the question of what directions the changes to the composition of the Federal Council are taking, as well as address the directions of evolutionary changes to the principles of electing the members of the Swiss government.
\end{abstract}

